\title{
THE TEACHER AS A CHILD-REARER OR THE TEACHER AS AN EDUCATOR. TWO VIEWS OF EDUCATION WORKERS ON THE TEACHER'S ROLE
}

\begin{abstract}
Teaching is a learned and practiced profession. In the course of their activities, the teacher influences the formation of attitudes, and the views and awareness of children and adolescents. Teaching should prepare young people "to independently manage the development of their own personality, to undertake valuable goals and to choose responsible life paths". The teacher's work situation results from the role that the teacher plays in the process of the socialization and education of children and adolescents. This article addresses the problem of the differentiation of the role of the teacher in the education process in Poland in terms of two variables - education and upbringing (child-rearing). It answers the question of whether and how the perception of the teaching profession has changed in the perception of people practicing this profession. How do teachers who are currently retired teachers see the profession and role of the teacher, and how are teachers currently practicing this profession? Is/was the Polish teacher a child-rearer or rather an educator, understood here as a person imparting knowledge? How does the occupation affect the perception of oneself, from the perspective of two groups of surveyed teachers (currently employed and retired)? All the reflections contained in the article are based on interviews with retired and currently working teachers. These interviews were part of a wider research project conducted in recent years by the author of the article in Polish educational institutions. The research took the form of ethnographic field research.
\end{abstract}

Keywords: teacher, role, educator, child-rearer, profession, unstructured interview, ethnography, observation, grounded theory.

\section{Introduction}

The education system in Poland is constantly changing. Every year, teachers face problems resulting from changes in the education law, work plan, textbook list, list of set books, changes made to school documents, changes to assessments (e.g. descriptive assessment in grades 1-3 of primary school), the definition of the

* Prof. of the University of Łódź, PhD hab., Department of the Sociology of Organization and Management, University of Łódź, ul. Rewolucji 1905 r. 41/43, 90-214 Łódź, e-mail: beata.pawlowska@uni.lodz.pl 
minimum teaching programme (curriculum), and changes to the school leaving qualification [General Certificate of Education (equivalent to the UK's GCSE level); matura/maturity diploma (equivalent to the UK's A Level)], and the lower secondary and primary school leaving examinations. These changes also concern the evaluation of their work, as well as the requirements for professional promotion. Over the past thirty years, in Poland we have had two revolutionary reforms in education, as a result of which gymnasiums (secondary or middle schools) were established in 1999, only to be liquidated in 2017 in a return to the eight-year primary school and three-year high school.

In their statements, the surveyed teachers (interviewees) emphasized that such frequent and serious changes in the education system cause enormous confusion and chaos in education, and lead to conflicts in educational institutions over the division of labor and the scope of duties. The same informants also argued that no reforms directly affected their perception of their professional role and school function.

The aim of this study is to show the role of the teacher as seen through the eyes of currently working and retired teachers. All the considerations refer to the educational activities undertaken by the interviewees in relation to their students. The focus is on the differences in the perception of the profession between teachers today and those who taught more than thirty years ago. The article deals with the problem of the diversification of the functions of the school, and the role of the teacher in the education process in Poland. It answers the question of whether the perception of the teaching profession has changed in the perception of people practicing this profession. In other words, do retired teachers see the teacher's role in the same way as current teachers? Is the Polish teacher a child-rearer or rather an educator, understood here as a person imparting knowledge and developing skills? How does the occupation affect the perception of oneself, from the perspective of two groups of surveyed teachers? Referring to the teachers' narrative about their work, I reconstruct the role of the teacher by relating it to the function of schools.

\section{Research methodology}

All the ideas contained in this article are based on my research on the emotions felt in relation to professional work, which I have recently carried out over the course of a few years in Polish educational institutions (schools as the teachers' workplace). The research was a field study and was based on two methodological approaches: ethnography (mainly organizational ethnography) and grounded theory (cf. Pawłowska 2013).

The ethnographic research I have conducted, on the basis of diverse case studies (see Prus 1997; Deegan 2001; Hammersley, Atkinson 2007), was 
designed in line with organizational ethnography, allowing the perspective of the organization participants to be understood and the study of both little known aspects and unusual areas of better known phenomena (Kostera 2012: 73; also see: Kostera 2003: 12; 2011: 9). It should be noted that ethnography allows for the collection of empirical data in everyday contexts in which the phenomena occur (see Prus 1997: 192; Deegan 2001; Kostera 2003: 12; Kostera 2011: 9; 2012 : 73; Hammersley, Atkinson 2007).

In order to deepen the insight into the examined reality, the number of cases was reduced to three primary and two junior high schools (see Burawoy 1998). Due to the specificity of ethnographic study, the school turned out to be a relatively closed system to which access requires "permission which, if granted, will take some time in obtaining" (Stein 2006: 70) and "strictly depends on the actual possession, holding the office, invitation or appointment" (Lofland et al. 2009: 63, cited in: Wojciechowska 2018). Considering the sensitivity of students' data, school principals were often reluctant to grant my access to the field. Some principals and teachers claimed that the researcher's "permanent" presence in the educational facility would disrupt the functioning of the school, thereby refusing my access to data. Instead, I was advised to leave a questionnaire to be completed by teachers - in order to minimize the researcher's contact with a given school. Thus, the choice of schools for the study was dictated by my access to data (see Silverman 2007). I had to take advantage of my informal contacts and connections (Konecki 2000: 171; also see Konecki 1998), and the number of schools was limited to five.

The methodology of grounded theory organized the research process and set the strategy for working with data. The methodology of grounded theory has been well described in the literature on the subject, therefore its detailed description will be omitted in this study (see Glaser, Strauss 1967; 2009; Strauss, Corbin 1997; Charmaz 2006; 2009; Konecki 2000; Gorzko 2008).

The research was based on an ethnographic study using triangulation, which allows a researcher to adopt different points of view and thus reach a distance to the analyzed data (Hammersley, Atkinson 2000). The study used data triangulation, methodological triangulation, and theoretical triangulation (see Denzin 1978; Konecki 2000: 86).

As part of the project (see Pawłowska 2013; Pawłowska 2019; 2020), I conducted a series of observations of school life and the work (cooperation) of teachers - with school staff, as well as students' parents. I also analyzed existing materials, such as school statutes, regulations, legal regulations, school operating programs, staff meeting protocols, school development plans, teachers' Level of Professional Promotion documents, websites etc. I also conducted informal conversations, and so-called conversational interviews (Konecki 2000) with school principals, teachers, other school employees and parents, and unstructured interviews and semi-structured interviews with current and retired teachers. The 
choice of interviewees was a deliberate, avalanche-like selection of a snowball (see Frankfort-Nachmias, Nachmias 2001: 199). The unstructured and conversational interviews became the basis for writing this article. There were 18 unstructured interviews with retired teachers and 42 unstructured interviews with current teachers, including school principals. The average duration of one interview was 39 minutes; however, some interviews, especially those with retired teachers, were much longer (over 2 hours). In the interviews, I attempted to draw attention to important elements of teachers' work, with particular emphasis on easy and difficult, pleasant and unpleasant, positive and negative situations. The interviews were conducted in places and at times convenient for the interviewees. Most often it was the informant or researcher's place of residence, a coffeehouse, teachers' lounge, or the principal's office. All interviews were audio recorded, transcribed, coded, and analyzed in accordance with the principles of grounded theory methodology. The application of grounded theory methodology is consistent with the adoption of the interpretative paradigm and allowed the capture of the processual dimension of constructing and giving meanings to studied phenomena, by comparing different cases in order to select from the collected material the basic concepts that constituted the basis for further comparisons (see Konecki 2000). The following grounded theory methodology procedures were used: substantial coding, including open coding, theoretical coding, memo-writing, diagramming.

\section{Profession as a sociological concept}

The concept of a profession is closely related to the concept of division of labor and ownership (see Przestalski 2008: 237, 260-261). This concept, along with many other terms in sociology, has not been given one consistent definition. In many dictionaries in the field of social sciences, including sociology, the term profession does not appear at all, or it is reduced to a one-sentence definition. In many other definitions, the authors refer to a classification of professions, which does not always seem to be correct. These classifications often refer to specific specialties and specializations, which results in confusion about the definition of the profession itself.

In the literature on the subject, two definitional problems are indicated. The first problem is related to the differentiation of a profession in terms of the scope of work specialization, where the profession is included only in the category of the position held within the performed and/or learned profession. The second problem is related to the issue of earnings, which is treated ambiguously. Although many definitions indicate that earnings function as a source of income (Weber 2002: 105-108; Giddens 2006: 397; Przestalski 2008: 238), the nature of such earnings is not mentioned. The profession determines a specific social position (Szczepański 1963: 199), which may extend to other family members. Activities resulting from the social division of labor (professional activities) "cause 
a particular mental and physical involvement of a given person, and also determine his function and social position, standard and lifestyle, as well as external appearance and behavior" (Sztumski 1981: 42-43).

In this study, I define a profession, following Everest Hughes, as "a relatively constantly performed set of activities aimed at producing specific items and services in order to meet needs" (Hughes 1958: 34). It is important that through the profession, a person evaluates himself, develops his opinion about himself, assigns value to himself and builds his groups of reference and identification (see Hughes 1958 and Konecki 1988). Occupation shapes the personality of an individual (see Ratajczak 2008: 48-49), and the choice of a field of study determines intellectual development and the system of values, aspirations and individual ambitions. The performed profession introduces a person in specific organizational forms, types of conflicts, types of employee relations and types of activities.

Teaching is a learned and practiced profession. Together with parents, the teacher should prepare young people "to manage their own personality development on their own, to undertake valuable goals and to choose their life paths responsibly" (Kaszubowska 2006: 55). This is also how I will understand child-rearing (upbringing) later in the article.

The practised profession is associated with adopting a specific role as an employee, which in turn leads to taking specific actions, revealing only certain aspects of one's personality in individual situations (see Park 1926), and involving interaction with a group of people accepting a given individual (Znaniecki 2011: 272). It should be emphasized that a specific social role determines the social self of an individual, that is, what the individual should be for themselves and others, and determines the set of rights and obligations assigned to the role assumed by the individual (see Znaniecki 1965; Szczepański 1972). In assuming the role of a teacher, the individual plays a role based on previous schemas and the socialization process, that is, presents what they consider appropriate for the role of the teacher. The individual is engaged in the process of interpreting the role in relation to the assumed scenario. The role of the teacher is also defined by the legislator, who states that the process of education and rearing of children and adolescents carried out by performing the following tasks:

- supporting each student in his development;

- striving for full personal development;

- professional development, according to the school's needs;

- educating young people to love their homeland, respecting the Constitution of the Republic of Poland, in an atmosphere of freedom of conscience and respect for every human being;

- taking care of shaping students' moral and civic attitudes in line with the idea of democracy, peace and friendship between people of different nations, races and worldviews (article 6, points 1-5, Teacher's Charter); 
- carrying out didactic, educational and caring activities conducted directly with or on behalf of students or pupils;

- carrying out other activities and activities resulting from the statutory tasks of the school, including care and educational activities that take into account the needs and interests of students;

- implementation of classes and activities related to preparation for classes, self-education and professional development (article 42, points 1-2, Teacher's Charter);

- be guided in one's activities with the welfare of students, concern for their health, moral and civic attitude, respecting the personal dignity of the student (article 5, Educational Law).

\section{Education and child-rearing (upbringing). The dispute over the role of the teacher and the functions of the school}

The role of a teacher is defined by a specific set of activities that a teacher should perform when fulfilling their duties. This role is clearly defined by the tasks and functions of the school. All the surveyed teachers are/were employees of educational institutions. Their role was mainly fulfilled in the workplace, but also outside of it. Speaking about their role, the informants identified it with the function of the institution in which they work/worked. They pointed out that they are/were also teachers outside the educational institution and when they address(ed) a student in a public place (outside the school premises) it is/ was dictated by the fact that they represent(ed) the school. In the narratives, when talking about their profession, they identified themselves with the place of work, using the terms: in our school, in my school, in my class, at our place, etc. There was a self-definition through participation in the school community. The informants changed "me" to "we" (school) and vice versa. The goal of the school was also the goal of the individual employee. Due to the fact of identifying with a given institution, the professional role overlapped with the function that the school should fulfill. The Teacher's Charter clearly defines the role and tasks of the teacher and identifies them with the school's function. The teacher is assessed in terms of the performance of the school's basic functions: didactic, educational and caring, and tasks related to the entrusted position, including tasks related to ensuring the safety of students during classes organized by the school (Art. 6 points 1-5, Teacher's Charter). Thus, the role of the teacher cannot be separated from that of the school.

Most theoreticians of pedagogy agree that the function of the school is teaching, training and upbringing, and the teacher is a rearer and an educator at the same time. In his text How to raise a school (1956), Leszek Bandura raised the problem of moral education and the role of the teacher in the process of education. 
In his opinion, the pedagogue plays a dominant role in the field of conscious and planned educational influence (see Rodziewicz 2003: 310-312). He assigned the teacher the role of a social activist (Mazur 2015: 107). He emphasized the teachers' high ideality, resulting from the shaped worldview and the sense of responsibility for the work they do (see Wołoszyn-Spirka 2001: 102-103).

Another educator and pedeutologist, Zygmunt Mysłakowski, who valued the teacher's educational activities very much, in 1970 extended the list of teaching tasks to include three basic terms (teaching, training, upbringing) with two additional ones: implementation and training. He claimed that:

1. We learn (and we teach) the knowledge, elementary skills of the language material, accounting and measurement operations, etc.

2. We implement habits and wonts.

3. We exercise praxia, elementary techniques, general physical dexterity, resourcefulness in practical life, tact (dexterity in behavior).

4. We educate functions (e.g. scientific thinking), beliefs, attitudes, worldview, aesthetic taste, creative skills, feelings.

5. We educate the whole person as an active and creative member of the community, sometimes in the sense of larger wholes, for example physical education (Mysłakowski 1970, cited in: Mazur 2015: 106).

Although child-rearing is sometimes equated with indoctrination, I would like to clearly emphasize that in this article it is understood as a process of the intentional shaping of the behaviors and attitudes adopted in a given culture and society. The education system is never free from ideology and religious and political doctrines, regardless of the existing political system. The educational function of the school, which I describe below, and as emphasized by the interviewees, relates to the transfer of positive models and taking actions that indicate to children and adolescents the values desired by society. Students come from a variety of families, including environmentally neglected ones. The role of the teacher is, among other things, to provide equal opportunities, not only intellectual ones:

Trips to the cinema, theater. Museums. Some people would not have had such opportunities if it were not for school [...]. And then how many times do you have to repeat how to behave. In order not to litter, not to make noise, not to dig in the chair, etc. [...] Oh, that's a lot. [...] And this is also upbringing (teacher in grades 1-3, primary school, woman, aged 48).

The teacher receiving the appointment (higher position) takes an oath in which he undertakes to be a child-rearer and guardian:

"I vow to diligently fulfill my duty as a teacher, educator and guardian of youth, strive for the full development of the student's and my own personality, educate and rear the young generation in the spirit of love for the homeland, national traditions, and respect for the Constitution of the Republic of Poland". The oath may be taken with the addition of the words: "So help me God" (art. 15 of the Teacher's Charter). 
Currently working teachers, although they are familiar with the norm indicating the educational function of the school, have not fully internalized it. This is especially noticeable when we relate the declarative layer to real action.

In the first phase of conducting interviews with active teachers and school principals, I had the feeling that all I heard were some empty slogans. They were providing information which, in their opinion, should be conveyed. Still, this did not, for the most part, reflect how they felt. For example, when the informants talked about the role of the teacher, I would hear, in the first part of the interview, that "school is a pedagogic and educational institution, and the task of the teacher is to prepare children and young people to function in society as best as possible". In the next statements, the educational function of the school was clearly emphasized, while marginalizing the pedagogic function (rearing, bringing up younger students). It was stressed that the main task of the school was to prepare children to pass an exam with a good grade, allowing them to successfully finish a given stage of education. However, the school tasks were often equated with individual teacher's tasks:

The school is to implement the program. This is the most important thing (a male high school teacher, aged 45).

Teachers are not for raising and do not raise children [...] parents should bring them up [...]. At school, the student is supposed to acquire knowledge (a female junior high school teacher, aged 31).

The role of a modern teacher has been reduced to being a person imparting knowledge, hereinafter referred to as "an educator" or "a craftsman". The most important value is that young people pass the exam at a good level, i.e. one that will allow students to continue their education in the school of their choice, and that will allow them to maintain their position in the ranking of schools or allow them to take a higher place in the ranking.

My goal is, first and foremost, to prepare the student for the A-level exam. Those three years of work in some way prepare them for the end of school, so that he can pass this high school diploma, so that he has a door for his future life (a male history teacher, high school teacher, aged 43).

Teachers in grades 1-3 also indicated the care function of the school, seeing themselves as taking care of the children entrusted to them. Most of the interviewees, although they were satisfied with the sympathy of the students, spoke negatively about the fact of the necessity to help students perform basic activities, such as getting dressed after PE lessons, tying shoes, teaching them to use scissors, for example, or dealing with emotionally and socially maladjusted students:

And he was not at all prepared by his parents for the fact that he was going to a new place and that he would be there, unfortunately; that he would have to be without his mother a bit. Well, there are children like that, and their parents could have prepared such holidays in some way during this period [...] (a female teacher of grades 1-3, primary school, aged 29). 
It is a girl and she is still very childish. She is not always able to submit to the group she works with. She does not always follow the teacher's instructions, or does it for a minute and then get distracted and doesn't do her work. So there is no such sense of duty and internal rigor, and she just approaches many things in a playful way. [...] She didn't feel safe because it was a new environment; large school, less intimate atmosphere than kindergarten. She was nervous, she waited for her mother, she was afraid that her mother would not come, she cried. Well, she had such pre-school behavior (a female teacher of grades 1-3, primary school, aged 46).

This student's social, emotional or intellectual maladjustment involves additional work for the teacher:

What if there are several such children in the class. Today more and more often, it's "this is ADHD, and this is exemption from PE, and this is dyslexia". Sometimes half a class has dyslexia. I mean, I don't know if they really have it, but there is a certificate, so you have to write a separate program for each. Well, it is, yes, it is a big obstacle for us (woman, teacher, primary school, aged 48).

Each dysfunction (e.g. dyslexia, dysgraphia, dysorthography, dyscalculia) is associated with the need to create an individual curriculum taking into account the dysfunction in question. The program (plan) of work with a dysfunctional child is submitted in the form of a document to the pedagogical council, and also for inspection by the parents (guardians) of the child. A few years ago, such a document had to be approved and signed by the parents, which involved the need to establish the content of the teacher's work program with a dysfunctional student with the parents (guardians). Teachers talked about communication difficulties with parents saying that they cannot "normally" work:

Parent had to sign. And sometimes such a parent is difficult to bring to school. He does not come to meetings. I pass the message to the student and nothing. There were times when such a work plan remained unsigned until the end of the semester. One of my friends had to go to the student's home after working hours to find her parents and ask for a signature. Usually, parents are surprised about what it is and why. Some people are not easy to convince [...] (a female math teacher, junior high school, aged 44).

Currently, the upbringing (rearing) function of the school is performed by educational institutions to a minimum extent:

The greatest role in shaping this process [rearing (upbringing) - ed. author] is played by the family, while educational institutions should play a supporting role. I also think that the disturbance of this relationship, especially when parents shift the responsibility for raising their children to institutions, adversely affects their process of development. Professional experience allows me to believe that such cases are not isolated (a female English teacher, primary school, aged 29).

According to the current teachers, family and parents (guardians) should be responsible for bringing children up (cf. Kowalczyk-Szajrych 2010). However, it is forgotten that children and teenagers spend up to eight or nine hours a day at school. This means that the process of socialization is somewhat dis- 
turbed: not having adult role models, young people refer to the behavior of their peers. The lack of clear educational activities on the part of the school and the lack of parents' time mean that educational activities focused on young people are generally not undertaken at all.

Florian Znaniecki, a classic scholar in the field of the sociology of upbringing (education), believed that child-rearing is a social process, and that the goals of education depend on the needs and aspirations of the social group it educates. According to Znaniecki (2011), the main educational environments are family, neighborhood, peer groups, school, and, extremely pertinent today, the broadly understood media. School was established as a complement to the family and neighborhood environment, but also in opposition to it. A feature of schools is a certain seclusion, which is necessary to focus benevolent influences and create a special environment. However, modern teachers argue that:

The assumption that school is a complementary environment does not hold true today. The demanding attitude of parents, the lack of involvement in the upbringing of their own children and difficulties in communicating with teachers make it extremely difficult for educational institutions to be the primary rearer environment for young people. Which there is no time for in the education process. In my professional work, I have experienced many times when the obligation to educate and build the right attitude of a child is transferred to the institution. Despite the obvious role and professional duties of the teacher, their striving and effort will not bring the expected results without the parent continuing this process. Lack of consistent messages at home and at school do not help the child's development, but they hinder it significantly (a female English teacher, primary school, aged 29).

In their interviews, the currently working teachers emphasized the passivity of parents as the main cause of educational problems that children and adolescents increasingly suffer from.

Besides, I believe that many of the children's rearing (upbringing) problems result from the negligence of their parents. Lack of interest in correcting the mistakes made by their children results in the development of bad habits and inappropriate behavior (a female Polish language teacher, junior high school, aged 39).

The literature on the subject emphasizes the importance of the education process in the activity of an educational institution. This is also how the teachers who are now retired saw their role. They mentioned the profession as a vocation, with the teacher having authority and being a role model in the process of socialization. The school was a place not only for education, but above all for child-rearing, and the teacher had authority and respect. Students modeled themselves on their masters, choosing a field of study and a future profession:

The leading places of students in Russian language competitions were a success. I am proud that several of my students graduated from Russian philology. One student even studied in Russia in St. Petersburg. That's nice (a female retired teacher, aged 77). 
The teacher was the person to whom the student could turn with the problem, who showed the way to solve the problem and shaped the personality of the student:

I have always believed that it was up to me as a teacher what kind of youth we would have. Today many educators complain about children, but what are they doing to help them? [...] How many times did I stay after school to explain not only tasks, but also how to act, how to react. The parents of my pupils worked hard and we taught them how to live. I don't know if I gave any good advice, but I tried my best [laughs] (a female retired teacher, aged 79).

Students came with various problems. There is not always a good educational atmosphere at home. They confided. Sometimes it was enough, so to speak, to talk. With some we spoke on first-name terms. They were almost grown-up people [...]. Yes, I still have contact with some of them today. They call me. They come by for tea. They tell about their children, grandchildren [...]. A teacher is a calling, not a profession. You cannot be a teacher only at school [...]. And when I met a student on the street, now he was an ex-student, I will also talk (a female retired teacher, aged 68).

The last statement shows how important the child-rearing function played by the teacher was. The informants considered the choice of this profession to be a kind of vocation. Another interviewee linked the role of a teacher as educator and teacher as rearer with the fact of constantly belonging to her first-class community:

And you know that I have contact with my first class all the time. They found me and we are meeting today on the occasion of Christmas, but not only. And it has been over fifty years since they finished primary school. They organize such meetings. They themselves meet several times a year and they always invite me. They're calling. Sometimes they tell different school stories. Some say they remember my advice, that I helped. As you know, I am lonely and they add joy to my old age (a female retired teacher, aged 84 ).

As you can see, there are significant differences in the perception of their role as teacher-child-rearer and teacher-educator among teachers. Retired teachers emphasized the balance between child-rearing (upbringing) and education. They also pointed out that this upbringing is often more important than education: "Knowledge is in books and studies, and indicating the right path - often priceless". It should be remembered that before the education reform of 1999, the matura (maturity diploma/A-level exams) was not a test. There were no exams for students finishing primary and secondary schools. Therefore, the teacher did not have to ensure that their students passed their school leaving exams well, as the result obtained by students in the entrance examinations to secondary and tertiary education was not related to the school's assessment and the achievement of high rates and places in school rankings. The matura examination was not a closedended or semi-open-ended test in which you should enter a specific answer, specified by the test creator. The matura examination allowed to students to make their own interpretation of the given topic, on the basis of their knowledge. Currently, the exam requires specific knowledge and leaves little room for logical thinking. 
Teachers are forced to teach in such a way that the student learns the facts that will be useful in the exam and will allow the student to guess the answers. Students in the last year of high school practice completing tests almost the entire school year. They learn how to construct a statement in order for it to be recognized by the teacher who checks the work (examiner). All this leads to the situation where the teacher becomes a "technician (craftsman/works man)" who transmits knowledge. The overloaded curriculum, as well as the enormity of bureaucratic work, often referred to by teachers as "papermaking" (in vivo code), means that the teacher has virtually no time for non-educational activities:

Starting some years ago, there was more emphasis on work with young people and the teacher was not burdened with various types of papers, the teacher was just doing his job. He was working. However, now [longer pause] he is working and writing, I should say so. What he does and what he doesn't write is not considered done. And he just writes and writes and only works. However, earlier it was the opposite. This is my impression (a female chemistry teacher, junior high school teacher, aged 48).

The respondents emphasize the difficulty of combining the work of a child-rearer with teaching and bureaucratic work. Magdalena Smak and Dominika Walczak (2015: 32) write that teachers and school principals feel that the number of documents they have to fill in, plans, reports, and statements means that their work is less about teaching and more about reporting. This greater emphasis on keeping school records is a factor indicating the transformation of modern schools in terms of their functions, which translates into teachers' perception of their role in the education and child-rearing process. The informants pointed to the increasing bureaucracy of the teaching process, which may result in level of education being lowered, and the rearing (upbringing) function of the school and the role of the teacher as a child-rearer being minimized.

Another distinguishing feature of the evolution of the teacher's role is significant individualisation and independence of work. Currently, teachers choose a specific teaching program (curriculum) themselves. The curriculum content is imposed and approved by the Ministry, however the teaching program and plan is developed individually by the teacher. The teacher can independently create a new plan and submit it for approval as the author's program. A modern teacher independently chooses the textbooks to be used by students. The situation was somewhat different in the communist period, where one textbook approved by the competent Ministry was required to teach the subject. The designs as well as the content of the approved textbooks have changed over the years. There was also one list of literary set books that was valid for all schools. The teacher was forced to discuss all the readings mentioned therein during the Polish language lesson. Currently, there is also a list of set books approved by the Ministry of Education, but the books have been divided into compulsory (so-called "with a star" or "starred" - in vivo codes) and supplementary, from which the teacher can discuss any chosen text, and within the scope he or she chooses. 
In both study groups, teachers indicated that the teaching methods used during the lessons were an individual choice of the teachers. It is they who decide whether it will work, on the basis of case studies, talks, lectures, work with the textbook, etc. It is they who decide whether during the classes for example the experiments (chemical) will be shown and whether the available multimedia will be used.

The perception of one's own professional role may also be influenced by the motives for choosing the occupation and by professional burnout. The random choice of profession and professional burnout direct the teachers' perception of their role as an educator and craftsman. The temporary nature of employment is not conducive to establishing an in-depth relationship with the student and solving educational problems:

I'm here by chance. I will work this year, maybe two, and if I find something else, I will move on.

Working with children is probably not for me (a male physics teacher, junior high school, aged 25).

In the statements of retired teachers, we can see that the choice of profession was not accidental. In the narratives of the respondents, there were stories about "playing the teacher" in childhood, about parents-teachers, and about dreams, convictions and the beliefs that appear in childhood about the future involvement in the teaching profession:

I often played at school and I like young people. When it was time to choose my profession, I didn't see myself anywhere else than at school. During my studies, I chose the teaching specialty (a female retired biology teacher, aged 68).

I've always wanted to be a teacher. I love children (a female retired kindergarten teacher, aged 69).

In some cases, this profession was inherited (cf. Pawłowska 2013), and many respondents came from families with a teaching tradition (cf. Mazurkiewicz 2003):

My mother was a teacher and so was her sister. My older sister too. So I had no choice [laughs] [...]. But it was a very rewarding job (a female retired math teacher, aged 68).

The current teachers, even when they started working for similar reasons as their older colleagues, spoke about unfavorable changes, about professional burnout and a decline in authority:

When I started working, I felt really good. I remember how proud I was to get the job. My mother was also very proud of me. She was also a teacher, so I grew up in the spirit that the teacher is an authority who provides a good education and fulfills this educational obligation. Today is different. Harder. Parents question our authority, but so do politicians [...]. This is not the same school (a female French teacher, high school, aged 53).

Many respondents, reflecting on the motive for choosing their profession, said that while had been observing their teachers they thought about also taking up teaching in the future. The teacher's authority, commitment and passion became a stimulus for the next generation of employees: 
Yes, yes, the decision to be a teacher was made in high school. I went to a class that was first class, a class that gave a beginning. It was a pedagogical class, I chose this class already then. I knew that my life would be related to teaching young people, definitely young people, not children (a female physics teacher, high school, aged 46).

Many of the respondents who are currently working teachers spoke about the temporary nature of work at school. They emphasized convenient and shorter working hours, longer holidays, and thus the possibility of better care for one's own children and easier organization of family life. Some people honestly pointed to the benefits in the form of tutoring or other additional paid lessons. Foreign language teachers mentioned the possibility of working in other language schools:

As you know, I teach German. At school, I have few hours and a permanent job. Here in primary school it's ok. But you can't earn too much [...]. Fortunately, there are private lessons. I also work in [here the name of a language school] [...] (a male German teacher, primary school, aged 31).

One of the factors that determine when a teacher enters school is the lack of other options. The inability to find a job in another institution, as well as bad experiences related to looking for a job connected with the completed field of study, which is less attractive at a given moment in the labor market, make the young person decide to work at school. Personal problems and/or the family situation mentioned above, including the need to look after a small child, are often an additional factor that leads people to work at school. In such a situation, the choice of profession becomes a necessity and is a negative choice. The future teacher starts working not because of passion, but because of compulsion:

I did not plan to be a teacher, everything just turned out that I went in this direction and just got a job at school, I couldn't find another job before. It all got complicated when I got pregnant in my fifth year of college, so it wasn't that easy either (a female geography teacher, secondary school, aged 33).

Coincidence, I got married, stayed in a small town, not in a city, and my job prospects changed. My friends informed me about a vacant position of a Polish teacher in one of the primary schools in a nearby town, and now, there were no other prospects, and I had to make a living on something (a female Polish teacher, primary school, aged 42).

My observations are confirmed by the research by Dominika Walczak (2012: 49), who states that men rarely declared that they had "always" been determined to work in the teaching profession. Most of them admitted that the choice of profession was made by chance. When choosing their university courses, they were guided mainly by the development of their own interests. The decision to supplement their education with a teacher training course was dictated primarily by the desire to acquire additional professional qualifications, resulted from the calculation of the chances of finding a job after graduation, and was made under the influence of friends from the same year. 
Many of my interviewees claimed that the choice of profession does not have to be carefully considered. They believed that taking up work in the profession and practice made it possible to clearly determine whether a given teacher is suitable for this profession:

I started working here because the German teacher I was looking for was employed on this basis, whether he wanted to work for a year and prove himself - on this basis. I said, okay, I will come here for a year, because then I will eliminate it, it will be clear that this is what I definitely do not want to do with my life. After which I did not want to do something else (a female German teacher, high school, aged 33).

At the same time, the interviewees noticed that few people who start work in the teaching profession subsequently leave it, which indicates that the teaching profession allows for permanent employment and for working in one place (one educational institution) for most of their professional career:

If someone does not quit the test period (internship), he or she works until retirement. Of course, there are cases when they close the class because there are fewer children, but then you go to the common room or graduate and teach a different subject. Sometimes someone goes abroad, with a husband, but as I say, it is rare, rather rare (a female teacher in grades 1-3, primary school, aged 40).

The research by Grzegorz Mazurkiewicz (2003) shows that out of thirty teachers, only four consciously chose this job as a dream job, which contrasts with the 1986 research (Bnińska et al.). A similar regularity is evident in my research, and that conducted by Małgorzata Bednarska (2009), who investigated extramural and full-time history students of the University of Wrocław and retirees and pensioners of the Polish Teachers Union "Wrocław Krzyki". The author notes that the choice of the teaching profession among future historians is dictated by the "lack of other perspectives" and "lack of knowledge about the cause", which means that the respondents do not know why they choose the teaching profession. These categories do not appear in the surveyed retired teachers, who declared that they had wanted to practice this profession from childhood, which was dictated by their love for children. The reasons mentioned by retired teachers also included the need to quickly become independent, the proximity of the school as a workplace, and the choice of parents (see Bednarska 2009: 328-330). On the basis of the cited studies, it can be concluded that the number of people choosing the teaching profession from the conviction of their own calling to this profession is decreasing, while the number of people who accidentally decide to become a teacher is increasing. Małgorzata Bednarska (2009: 328-329) writes that "for today's youth preparing to teach others, the student becomes less important (decrease in motivation - wwork with children/youth $\ll)$, and more important is own person (increase in motivation - $\gg$ interests «)". It certainly translates into the role perceived and performed by teachers. 


\section{Conclusion}

A teacher's place of work is a school, usually understood as an educational institution. However, the school is also, and perhaps above all, the students who spend 5 to even 9 hours a day within its walls. Children and adolescents not only acquire knowledge here, but also undergo the process of socialization. Peers and teachers have a significant influence on the formation and appearance of certain behaviors and actions.

The above analyses showed clear differences in how teachers perceive their profession and role. The informants referred to the changes in the teacher's authority (cf. Pawłowska 2013; 2016) and changes in the attitudes of parents. Many of the factors constituting the role of a teacher (permanent employment, stress, teaching methods, changing working conditions, i.e. the provisions of the education law, including the Teacher's Charter), in the opinion of the respondents, have not changed over the last fifty years, but the perception of the role has changed. The student-teacher and teacher-parent relationships changed, which forced them to change their activities and interactions.

The aim of the article was to show the role of the teacher in the context of a child-rearer and/or educator in relation to two groups of teachers (retired and currently working). As the interviewees pointed out, a modern teacher is mainly an educator who has to prepare young people to pass exams, mainly in the form of a test. Some informants called these actions "testomania" (in vivo code). They said that every exam comes with an answer key that defines the correct answers. One of the informants stated that "This should be taught so that the student has no doubts about the interpretation". High school students in their final year practice completing tests almost the entire school year. They learn how to construct a statement in order for it to be recognized by the teacher checking the work (the external examiner). Therefore, in the teaching process, there is no place for the students' opinions, for their dilemmas and interpretations, or for simply independent thinking. The teacher is not (or cannot be) a person who shows the path of development, stimulates independent thinking, to ask questions and seek answers to them through discussion and mutual respect, but is only a technician (craftsman) who will teach how to solve a test, how to guess the correct answer specified by the answer key.

Contemporary teachers also point to the progressive bureaucratization of their work, which they call "paperwork", which, they claim, means that the teacher basically has no time for activities other than educational ones. Considering today's easy access to knowledge through the media and Internet resources, and the widespread participation of young people in additional classes and tutoring, in which both weaker and very good students participate, it is perhaps surprising that it is the teachers who today emphasize their role as educators, marginalizing the role of child-rearers. The respondents who are currently working teachers clearly 
emphasized the educational function of the school in their statements, taking the position that the family is responsible for upbringing. Retired teachers emphasized the balance between child-rearing (upbringing) and education. The role of the teacher has evolved from teacher-rearer to teacher-educator. The emphasis has shifted from rearing (upbringing) to education and knowledge transfer. We should remember that the school, regardless of the formal definition of its function, has and will continue to play a socializing role. Teachers should see their great importance in the process of educating and shaping the personality and self-esteem of a child. This is especially important in the world of consumerism and busy parents. Often, it is the teacher who becomes trusted and becomes the confidant of the students', with regard to concerns and problems, which, for various reasons, they cannot share with their parents.

\section{Bibliography}

Bandura L. (1956), Poglady pedagogiczne Stanisława Staszica, Państwowe Zakłady Wydawnictw Szkolnych, Warszawa.

B e d n ar s k a M. (2009), Dlaczego ludzie zostają nauczycielami? Studium porównawcze "dawniej i dziś" na podstawie badań własnych, [in:] S. Popek, A. Winiarz (eds.), Nauczyciel. Zawód, powołanie, pasja, Wydawnictwo Uniwersytetu Marii Curie-Skłodowskiej, Lublin.

Bnińska Z., Grotowska-Leder J., Kawka Z., Krzyszkowski J., Rokicka E., Taran M., Falecki W. (1986), Nauczyciel o swojej pracy. Raport z badań, Zakład Socjologii Ogólnej Uniwersytetu Łódzkiego, Łódź.

Burawoy M. (1998), The extended case method, "Sociological Theory", vol. 16(1).

Charmaz K. (2006), Constructing Grounded Theory: A practical guide through qualitative analysis, Sage, London-Thousand Oaks-New Delhi.

Charmaz K. (2009), Teoria ugruntowana. Praktyczny przewodnik po analizie jakościowej, transl. B. Komorowska, Wydawnictwo Naukowe PWN, Warszawa.

Deegan M.J. (2001), The Chicago School of Ethnography, [in:] P. Atkinson, A. Coffey, S. Delamont, J. Lofland, L. Lofland (eds.), Handbook of Ethnography, Sage, Thousand Oaks.

Denzin N.K. (1978), The Research Act: A theoretical introduction to sociological methods, McGraw-Hill, New York.

Frankfort-Nachmias C., Nachmias D. (2001), Metody badawcze w naukach społecznych, transl. E. Hornowska, Zysk i S-ka, Poznań.

Giddens A. (2006), Socjologia, transl. A. Szulżycka, Wydawnictwo Naukowe PWN, Warszawa.

Glaser B.G., Strauss A.L. (1967), The Discovery of Grounded Theory: Strategies for qualitative research, Adline Publishing Company, New York.

Glaser B.G., Strauss A.L. (2009), Odkrywanie teorii ugruntowanej: strategie badania jakościowego, transl. M. Gorzko, Zakład Wydawniczy "Nomos”, Kraków.

Gorzko M. (2008), Procedury i emergencja. O metodologii klasycznych odmian teorii ugruntowanej, Wydawnictwo Uniwersytetu Szczecińskiego, Szczecin.

Hammersley M., Atkinson P. (2000), Metody badań terenowych, transl. S. Dymczyk, Zysk i S-ka, Poznań.

Hammersley M., Atkinson P. (2007), Ethnography. Principles in practice, Taylor and Francis, New York.

Hughes E.C. (1958), Men and Their Work, The Free Press, Glencoe. 
Kaszubowska U. (2006), Nauczyciel wobec wyzwań przyszłości - dylematy i nadzieje, [in:] E. Perzycka (ed.), Nauczyciel jutra, Wydawnictwo Adam Marszałek, Toruń.

Konecki K. (1988), Praca w koncepcji socjologii interakcjonistycznej, "Studia Socjologiczne", vol. 1(108), pp. 225-245.

Konecki K. (1998), Łowcy głów. Headhunting: analiza pracy rekrutacyjnej w agencjach doradztwa personalnego, Wydawnictwo Normalizacyjne Alfa-Wero, Warszawa.

Konecki K. (2000), Studia z metodologii badań jakościowych. Teoria ugruntowana, Wydawnictwo Naukowe PWN, Warszawa.

Kostera M. (2003), Antropologia organizacji: metodologia badań terenowych, Warszawa, Wydawnictwo Naukowe PWN.

Kostera M. (2012), Etnografia socjologiczna, [in:] K. Konecki, P. Chomczyński (eds.), Słownik socjologii jakościowej, Difin, Warszawa.

Kostera M. (ed.) (2011), Etnografia organizacji. Badania polskich firm i instytucji, Gdańskie Wydawnictwo Psychologiczne, Sopot.

Kowalczyk-Szajrych M. (2010), Opinie nauczycieli nauczania zintegrowanego łódzkich szkót na temat poprawek wprowadzonych do ustawy o systemie oświaty, niepublikowana praca licencjacka napisana pod kierunkiem naukowym dr hab. Alicji Łaskiej-Formejster w Instytucie Socjologii Uniwersytetu Łódzkiego.

Lofland J., Snow D., Anderson L., Lofland L. (2009), Analiza układów społecznych, transl. A. Kordasiewicz, S. Urbańska, M. Żychlińska, Wydawnictwo Naukowe Scholar, Warszawa.

Mazur P. (2015), Zawód nauczyciela w ciagu dziejów. Skrypt dla studentów z historii wychowania, Państwowa Wyższa Szkoła w Chełmie, Chełm.

Mazurkiewicz G. (2003), Odcienie szarości. Nauczyciele - doświadczenia i postawy wobec zawodu. Raport z badań, Zespół Szkół Ogólnokształcących nr 5, II Liceum Ogólnokształcące, Zabrze.

Mysłakowski Z. (1970), Proces kształcenia i jego wyznaczniki, Państwowe Zakłady Wydawnictw Szkolnych, Warszawa.

Park R.E. (1926), Behind our masks, "The Survey", May.

Pawłowska B. (2013), Emocje spoleczne w pracy nauczyciela i przedstawiciela handlowego, Wydawnictwo Uniwersytetu Łódzkiego, Łódź.

Pawłowska B. (2016), Autorytet jako czynnik ułatwiajacy radzenie sobie z negatywnymi emocjami w pracy nauczyciela, [in:] J. Moos, M. Kułak (eds.), Przemiany w edukacji zawodowej w kontekście relacji szkoła - rynek pracy, Łódzkie Centrum Doskonalenia Nauczycieli i Kształcenia Praktycznego, Łódź, pp. 75-89.

Pawłowska B. (2019), Poszukiwanie tożsamości przez badacza w kontekście etnograficznego badania emocji w pracy nauczyciela, "Przegląd Socjologii Jakościowej”, vol. 15, no. 1, pp. $154-177$.

Pawłowska B. (2020), Pride in teachers' everyday work. Conditions and contexts, "Qualitative Sociology Review", vol. 16(1), pp. 28-48.

Prus R. (1997), Subcultural Mosaics and Intersubjective Realities. An ethnographic research agenda for pragmatizing the social sciences, State University of New York Press, New York.

Przestalski A. (2008), Zawód i sposoby jego analizy $w$ dawnej $i$ nowej socjologii, [in:] S. Banaszak, K. Doktór (eds.), Problemy socjologii gospodarki, Wydawnictwo Wyższej Szkoły Komunikacji i Zarządzania, Poznań.

Ratajczak Z. (2008), Psychologia pracy i organizacji, Wydawnictwo Naukowe PWN, Warszawa.

Rodziewicz E. (2003), Bandura Ludwik Ryszard, [in:] T. Pilch (ed.), Encyklopedia pedagogiczna XXI wieku, vol. 1, Wydawnictwo Akademickie "Żak", Warszawa.

Silverman D. (2007), Interpretacja danych jakościowych, transl. M. Głowacka-Grajper, J. Ostrowska, Wydawnictwo Naukowe PWN, Warszawa. 
Smak M., Walczak D. (2015), Pozycja społeczno-zawodowa nauczycieli. Raport z badania jakościowego, Instytut Badań Edukacyjnych, Warszawa.

Stein M. (2006), Your place or mine: the geography of social research, [in:] D. Hobbs, R. Wright (eds.), The Sage Handbook of Fieldwork, Sage, London-Thousand Oaks-New Delhi, pp. 59-76.

Strauss A.L., Corbin J. (1997), Grounded Theory in Practice, Sage, Thousand Oaks.

Szczepański J. (1963), Socjologiczne zagadnienie wyższego wykształcenia, Państwowe Wydawnictwo Naukowe, Warszawa.

Szczepański J. (1972), Elementarne pojęcia socjologii, Państwowe Wydawnictwo Naukowe, Warszawa.

Sztumski J. (1981), Socjologia pracy w zarysie, Instytut Wydawniczy Związków Zawodowych, Warszawa.

Ustawa z dnia 26 stycznia 1982 r. - Karta Nauczyciela, Dz.U. z 1982 r. Nr 3, poz. 19, z późniejszymi zmianami (tekst jednolity) oraz Dz.U. z 2019 r., poz. 2215.

Walczak D. (2012), Badanie poczatkujących nauczycieli. Początkujący nauczyciele. Raport z badania jakościowego, Instytut Badań Edukacyjnych, Warszawa.

Weber M. (2002), Gospodarka i spoteczeństwo, transl. D. Lachowska, Wydawnictwo Naukowe PWN, Warszawa.

Wojciechowska M. (2018), Doing research on behind-the-scenes phenomena: entering the female escort industry, [in:] S. Kleinknecht, L-J.K. van den Scott, C. Sanders (eds.), The Craft of Qualitative Research, Canadian Scholars' Press, Toronto, pp. 133-139.

Wołoszyn-Spirka W. (2001), W poszukiwaniu realistycznych podstaw moralnego postepowania nauczyciela, Wydawnictwo Uczelniane Akademii Bydgoskiej im. Kazimierza Wielkiego, Bydgoszcz.

Znaniecki F. (1965), Social Relations and Social Roles, Chandler Publishing Company, San Francisco.

Znaniecki F. (2011), Relacje spoleczne i role spoleczne, transl. E. Hałas, Wydawnictwo Naukowe PWN, Warszawa.

\title{
WYCHOWAWCA CZY EDUKATOR. DWA SPOJRZENIA PRACOWNIKÓW OŚWIATY NA ROLĘ NAUCZYCIELA
}

\begin{abstract}
Abstrakt. Nauczyciel to zawód wyuczony i wykonywany. Nauczyciel w toku podejmowanych przez siebie działań wpływa na kształtowanie postaw, poglądów i świadomość dzieci i młodzieży. Powinien przygotować on młodzież „do samodzielnego kierowania rozwojem własnej osobowości, do podejmowania wartościowych celów i odpowiedzialnego wyboru dróg życiowych". Sytuacja pracy nauczyciela wynika z roli, jaką nauczyciel pełni w procesie socjalizacji i kształcenia dzieci i młodzieży.

Niniejszy artykuł podejmuje problem zróżnicowania roli nauczyciela w procesie edukacji w Polsce w kontekście dwóch zmiennych - edukacji i wychowania. Odpowiada na pytanie, czy i jak zmieniło się postrzeganie zawodu nauczyciela w percepcji osób wykonujących ten zawód. Jak zawód i rolę nauczyciela widzą/widzieli nauczyciele emerytowani, a jak nauczyciele obecnie wykonujący ten zawód? Czy polski nauczyciel jest/był wychowawcą, czy raczej edukatorem, rozumianym tutaj jako osoba przekazująca wiedzę?

Całość zawartych w artykule przemyśleń bazuje na wywiadach przeprowadzonych z nauczycielami emerytowanymi i obecnie pracującymi. Wywiady te były elementem szerszego projektu badawczego prowadzonego przez autorkę artykułu w ciągu ostatnich lat w polskich instytucjach edukacyjnych. Badania miały charakter etnograficznych badań terenowych.
\end{abstract}

Słowa kluczowe: nauczyciel, zawód, praca, etnografia, wywiad swobodny, obserwacja, teoria ugruntowana. 